\title{
Synthesis, molecular and electronic structures of half-sandwich ruthenium(II) complexes with pyrimidine-based ligands
}

\author{
J. G. Małecki
}

Received: 12 May 2010/Accepted: 1 July 2010/Published online: 16 July 2010

(C) The Author(s) 2010. This article is published with open access at Springerlink.com

\begin{abstract}
The complexes $\left[\left(\mathrm{C}_{6} \mathrm{H}_{6}\right) \mathrm{RuCl}_{2}(\mathrm{Hmtp})\right]$ and $\left[\left(\mathrm{C}_{6} \mathrm{H}_{6}\right)-\right.$ $\left.\mathrm{RuCl}_{2}\left(\mathrm{C}_{4} \mathrm{H}_{4} \mathrm{~N}_{2}\right)\right]$ have been prepared and studied by IR, ${ }^{1} \mathrm{H}$ NMR, UV-VIS spectroscopy and X-ray crystallography. The complexes were prepared by reactions of $\left[\left(\mathrm{C}_{6} \mathrm{H}_{6}\right)\right.$ $\left.\mathrm{RuCl}_{2}\right]_{2}$ with 7-hydroxy-5-methyl[1,2,4]triazolo[1,5-a]pyrimidine (Hmtp) and pyrimidine, respectively, in methanol. The electronic structures and UV-Vis spectra of the complexes have been calculated using the TD-DFT method.
\end{abstract}

\section{Introduction}

In the chemistry of ruthenium, the coordination chemistry of complexes containing $N$-heterocyclic derivatives is one of the most studied aspects. The wide interest is this field originates from the very rich redox chemistry and photophysics of these compounds. Even small changes in the coordination environment around the ruthenium can play a key role in altering the redox properties of the complexes, and thus, complexation of ruthenium by various ligands is very interesting and has been widely studied [1-4].

The $\eta^{6}$-arene-ruthenium complexes play a vital role in organometallic chemistry [5-7]. The arene-ruthenium halide compounds are key starting materials for the formation of a wide range of neutral and cationic ligand derivatives [8-11]. The half-sandwich arene-ruthenium complexes may serve as excellent catalyst precursors for hydrogenation and for ring-opening metathesis polymerization. Some studies of arene-ruthenium complexes have shown that they can inhibit cancer cell growth [12-15].

J. G. Małecki ( $\square)$

Department of Crystallography, Institute of Chemistry,

University of Silesia, 9th Szkolna St., 40-006 Katowice, Poland

e-mail: gmalecki@us.edu.pl
The triazolopyrimidine ligands are interesting due to their biological activity. The triazolopyrimidine derivatives are examples of purine mimics, and 7-hydroxy-5-methyl $[1,2,4]$ triazolo[1,5-a]pyrimidine (Hmtp) Hmtp is a good representative of these derivatives.

The complexes reported in this paper combine our interest in ruthenium coordination compounds and complexes containing Hmtp or pyrimidine. I present the synthesis, crystal, molecular and electronic structures, and the spectroscopic characterization of these new half-sandwich ruthenium(II) complexes.

\section{Experimental}

The starting material $\left[\left(\mathrm{C}_{6} \mathrm{H}_{6}\right) \mathrm{RuCl}_{2}\right]_{2}$ was synthesized according to the literature procedure [16, 17]. All other reagents were commercially available and were used without further purification.

Synthesis of the complexes

A mixture of $\left[\left(\mathrm{C}_{6} \mathrm{H}_{6}\right) \mathrm{RuCl}_{2}\right]_{2}\left(0.25 \mathrm{~g} ; 5 \times 10^{-4} \mathrm{~mol}\right)$ and 5-methyl-7-hydroxy-1,2,4-triazolo-[1,5- $\alpha]$ pyrimidine or pyrimidine $\left(7 \times 10^{-4} \mathrm{~mol}\right)$ in methanol $\left(50 \mathrm{~cm}^{-3}\right)$ was refluxed for $3 \mathrm{~h}$, cooled and filtered. Crystals suitable for $\mathrm{X}$-ray crystal analysis were obtained by slow evaporation of the filtrate.

Complex 1

[( $\left.\left.\mathrm{C}_{6} \mathrm{H}_{6}\right) \mathrm{RuCl}_{2}(\mathrm{Hmtp})\right]$, Yield 82\%. IR (KBr): 3,410 ( $\left.v_{\mathrm{OH}}\right)$, 3,214 $\left(v_{\mathrm{CH}}\right), 3,120\left(v_{\mathrm{CH}}\right), 3,062\left(v_{\mathrm{CH}}\right), 1,720\left(v_{\text {ring }}\right), 1,636$ $\left(v_{\mathrm{CN}}\right), 1,490\left(v_{\mathrm{C}=\mathrm{C}}\right), 1,435\left(v_{\text {ring }}+v_{\mathrm{CH}}\right), 1,325\left(\delta_{\mathrm{CH}}\right), 1,142$ $\left(\delta_{\mathrm{CH}}\right), 898\left(\gamma_{\mathrm{CH}}\right), 529\left(v_{\mathrm{Ru}-\mathrm{N}}\right)$. UV-VIS (acetonitrile, 
$\lambda[\mathrm{nm}](\log \varepsilon)): 445.0$ (1.37), 337.2 (1.96), 272.3 (3.22), 233.7 (3.18) sh, 213.3 (3.77). ${ }^{1} \mathrm{H}$ NMR: $\left(\mathrm{CDCl}_{3}, \mathrm{ppm}\right)$ : $8.36(\mathrm{~s}, \mathrm{OH}), 7.54(\mathrm{~s}, \mathrm{H} 2), 7.02(\mathrm{~s}, \mathrm{H} 6), 5.89\left(\mathrm{~s}, \mathrm{C}_{6} \mathrm{H}_{6}\right), 2.38$ $\left(\mathrm{s}, \mathrm{CH}_{3}\right)$.

\section{Complex 2}

$\left[\left(\mathrm{C}_{6} \mathrm{H}_{6}\right) \mathrm{RuCl}_{2}\left(\mathrm{C}_{4} \mathrm{H}_{4} \mathrm{~N}_{2}\right)\right]$, Yield 87\%. IR (KBr): 3,071 $\left(v_{\mathrm{CH}}\right), 1,582\left(v_{\mathrm{CN}}\right), 1,505\left(v_{\mathrm{C}=\mathrm{C}}\right), 1,435\left(v_{\text {ring }}+v_{\mathrm{CH}}\right), 1,399$ $\left(\delta_{\mathrm{CH}}\right), 1,140\left(\delta_{\mathrm{CH}}\right), 828\left(\gamma_{\mathrm{CH}}\right), 451\left(v_{\mathrm{Ru}-\mathrm{N}}\right)$. UV-VIS (methanol, $\lambda[\mathrm{nm}](\log \varepsilon))$ : 409.9 (1.46), 302.1 (1.98), 270.9 (2.76), 231.3 (3.12) sh, 212.6 (3.62). ${ }^{1} \mathrm{H}$ NMR: $\left(\mathrm{CDCl}_{3}\right.$, ppm): 9.27 (s, H2), 8.79 (s, H4,6), 7.39 (s, H5), 5.76 (s, $\left.\mathrm{C}_{6} \mathrm{H}_{6}\right)$.

\section{Physical measurements}

Infrared spectra were recorded on a Nicolet Magna 560 spectrophotometer in the spectral range $4,000 / 400 \mathrm{~cm}^{-1}$ using $\mathrm{KBr}$ pellets. Electronic spectra were measured on a Lab Alliance UV-VIS 8,500 spectrophotometer in the range of $600-180 \mathrm{~nm}$ in methanol solution. ${ }^{1} \mathrm{H}$ NMR spectra were obtained at room temperature in $\mathrm{CDCl}_{3}$ using a Bruker 400 spectrometer.

\section{DFT calculations}

The calculations were carried out using the Gaussian09 $[18,19]$ program. The DFT/B3LYP [20] method was used for the geometry optimization and electronic structure determination, and electronic spectra were calculated by the TD-DFT [21] method. The calculations were performed using the DZVP basis set [22, 23] with $f$ functions with exponents 1.94722036 and 0.748930908 on ruthenium, and polarization functions for all other atoms: 6-31 $\mathrm{g}(2 \mathrm{~d}, \mathrm{p})$-chlorine, 6-31 $\mathrm{g} * *$ —carbon, nitrogen and 6-31 g(d,p) - hydrogen. The PCM solvent model was used in the Gaussian calculations with acetonitrile as the solvent. GaussSum 2.2 [24] was used to calculate group contributions to the molecular orbitals and to prepare the partial density of states (DOS) and overlap population density of states (OPDOS) spectra. The contribution of a group to a molecular orbital was calculated using Mulliken population analysis. The PDOS and OPDOS spectra were created by convoluting the molecular orbital information with Gaussian curves of unit height and FWHM of $0.3 \mathrm{eV}$.

Crystal structure determination and refinement

Red crystals of $\left[\left(\mathrm{C}_{6} \mathrm{H}_{6}\right) \mathrm{RuCl}_{2}(\mathrm{Hmtp})\right]$ and $\left[\left(\mathrm{C}_{6} \mathrm{H}_{6}\right)-\right.$ $\mathrm{RuCl}_{2}\left(\mathrm{C}_{4} \mathrm{H}_{4} \mathrm{~N}_{2}\right)$ ] were mounted in turn on an Xcalibur, Atlas, Gemini ultra Oxford Diffraction automatic diffractometer, equipped with a CCD detector and used for data collection. X-ray intensity data were collected with graphite monochromated $\operatorname{Mo} K_{\alpha}$ radiation $(\lambda=0.71073 \AA)$ at temperature $295.0(2) \mathrm{K}$, with $\omega$ scan mode. Ewald sphere reflections were collected up to $2 \theta=50.10^{\circ}$ and $57.54^{\circ}$ for complexes $\mathbf{1}$ and $\mathbf{2}$, respectively. The unit cell parameters were determined from least-squares refinement of the setting angles of 13,309 and 12,292 strongest reflections. Details concerning crystal data and refinement are gathered in Table 1. During the data reduction, the decay correction coefficients were taken into account. Lorentz, polarization and numerical absorption corrections were applied. The structures were solved by the Patterson method. All the non-hydrogen atoms were refined anisotropically using full-matrix, least-squares technique on $\mathrm{F}^{2}$. All the hydrogen atoms were found from difference Fourier synthesis after four cycles of anisotropic refinement and refined as "riding" on the adjacent atoms with individual isotropic temperature factor equal 1.2 times the value of equivalent temperature factor of the parent atom, with geometry idealization after each cycle. The Olex2 [25] program was used for all the calculations. Atomic scattering factors were those incorporated into the computer programs.

\section{Results and discussion}

The half-sandwich complexes were obtained by the reaction of $\left[\left(\mathrm{C}_{6} \mathrm{H}_{6}\right) \mathrm{RuCl}_{2}\right]_{2}$ with Hmtp or pyrimidine in methanol solutions. In the IR spectrum of complex 1, the ring $\mathrm{C}=\mathrm{C}$ and $\mathrm{C}=\mathrm{N}$ stretching modes of the Hmtp ligand are present at 1,720 and $1,636 \mathrm{~cm}^{-1}$, and for complex 2 , the pyrimidine $\mathrm{C}=\mathrm{C}$ and $\mathrm{C}=\mathrm{N}$ stretches are found at $1,582 \mathrm{~cm}^{-1}$. The stretching modes of the $\mathrm{C}-\mathrm{H}$ are observed at $3,214,3,120,3,062$ and $3,071 \mathrm{~cm}^{-1}$, for complexes $\mathbf{1}$ and $\mathbf{2}$, respectively. The phenyl ring $\mathrm{C}-\mathrm{H}$ bend mode is visible in the bands with maxima at $1,490,1,435$, $1,325 \mathrm{~cm}^{-1}$ in $\mathbf{1}$, and $1,505,1,435,1,398 \mathrm{~cm}^{-1}$ in $\mathbf{2}$. The methyl group (Hmtp) $\mathrm{C}-\mathrm{H}$ bend mode has a maximum at $1,142 \mathrm{~cm}^{-1}$. The twist mode of benzene $\mathrm{C}-\mathrm{H}$ is at 898 and $896 \mathrm{~cm}^{-1}$ for compounds $\mathbf{1}$ and $\mathbf{2}$, respectively. The stretching frequency of the Ru-N bond is at $529 \mathrm{~cm}^{-1}$ in complex 1 and $451 \mathrm{~cm}^{-1}$ in 2 . In the ${ }^{1} \mathrm{H}$ NMR spectra of the complexes, the protons of the $\mathrm{C}_{6} \mathrm{H}_{6}$ ligands appear as a singlet at 5.89 and $5.76 \mathrm{ppm}$, respectively, for complexes 1 and 2. The $\mathrm{OH}$ proton of Hmtp appears at $8.36 \mathrm{ppm}$.

\section{Crystal structures}

The complexes $\mathbf{1}$ and $\mathbf{2}$ crystallize in the monoclinic space groups $\mathrm{C} 2 / \mathrm{c}$ and $\mathrm{P} 2{ }_{1} / \mathrm{c}$, respectively. The molecular structures of the compounds are shown in Fig. 1. Selected bond lengths and angles are listed in Table 2. The complexes 
Table 1 Crystal data and structure refinement details of $\left[\left(\mathrm{C}_{6} \mathrm{H}_{6}\right)\right.$ $\left.\mathrm{RuCl}_{2}(\mathrm{Hmtp})\right] \cdot \mathrm{CH}_{3} \mathrm{OH}(\mathbf{1})$ and $\left[\left(\mathrm{C}_{6} \mathrm{H}_{6}\right) \mathrm{RuCl}_{2}\left(\mathrm{C}_{4} \mathrm{H}_{4} \mathrm{~N}_{2}\right)\right]$ (2)

\begin{tabular}{|c|c|c|}
\hline & 1 & 2 \\
\hline Empirical formula & $\mathrm{C} 12 \mathrm{H} 11 \mathrm{Cl} 2 \mathrm{~N} 4 \mathrm{ORu}$ & $\mathrm{C} 10 \mathrm{H} 10 \mathrm{Cl} 2 \mathrm{~N} 2 \mathrm{Ru}$ \\
\hline Formula weight & 399.22 & 330.175 \\
\hline Temperature $[\mathrm{K}]$ & $295.0(2) \mathrm{K}$ & $295.0(2) \mathrm{K}$ \\
\hline Crystal system & Monoclinic & Monoclinic \\
\hline Space group & $\mathrm{C} 2 / \mathrm{c}$ & $\mathrm{P} 2(1) / \mathrm{c}$ \\
\hline \multicolumn{3}{|l|}{$\begin{array}{l}\text { Unit cell } \\
\text { dimensions }\end{array}$} \\
\hline $\mathrm{a}[\AA]$ & $19.3477(4)$ & $12.4609(3)$ \\
\hline $\mathrm{b}[\AA]$ & $12.16787(18)$ & $7.28521(16)$ \\
\hline$c[\AA]$ & $13.1035(3)$ & $12.3118(3)$ \\
\hline$\beta$ & $113.873(3)$ & $99.586(2)$ \\
\hline Volume $\left[\AA^{3}\right]$ & $2,820.89(10)$ & $1,102.06(4)$ \\
\hline $\mathrm{Z}$ & 8 & 4 \\
\hline $\begin{array}{l}\text { Calculated density } \\
{\left[\mathrm{Mg} / \mathrm{m}^{3}\right]}\end{array}$ & 1.880 & 1.983 \\
\hline $\begin{array}{l}\text { Absorption } \\
\text { coefficient } \\
{\left[\mathrm{mm}^{-1}\right]}\end{array}$ & 1.489 & 1.856 \\
\hline $\mathrm{F}(000)$ & 1,576 & 648 \\
\hline $\begin{array}{l}\text { Crystal } \\
\text { dimensions } \\
{[\mathrm{mm}]}\end{array}$ & $0.368 \times 0.113 \times 0.089$ & $0.107 \times 0.062 \times 0.060$ \\
\hline $\begin{array}{l}\theta \text { range for data } \\
\text { collection }\left[{ }^{\circ}\right]\end{array}$ & $3.40-25.05$ & $4.31-28.70$ \\
\hline \multirow[t]{3}{*}{ Index ranges } & $-22 \leq \mathrm{h} \leq 22$ & $-16 \leq \mathrm{h} \leq 16$ \\
\hline & $-14 \leq \mathrm{k} \leq 14$ & $-10 \leq \mathrm{k} \leq 9$ \\
\hline & $-15 \leq 1 \leq 15$ & $-16 \leq 1 \leq 15$ \\
\hline $\begin{array}{c}\text { Reflections } \\
\text { collected }\end{array}$ & 13,309 & 12,292 \\
\hline $\begin{array}{l}\text { Independent } \\
\text { reflections }\end{array}$ & $2,496[R($ int $)=0.0225]$ & $2,745\left[R\left({ }_{\mathrm{int}}\right)=0.0860\right]$ \\
\hline $\begin{array}{l}\text { Data/restraints/ } \\
\text { parameters }\end{array}$ & $2,496 / 0 / 185$ & $2,745 / 0 / 137$ \\
\hline $\begin{array}{l}\text { Goodness-of-fit } \\
\text { on } F^{2}\end{array}$ & 1.169 & 0.963 \\
\hline \multirow{2}{*}{$\begin{array}{l}\text { Final } R \text { indices } \\
\quad[I>2 \sigma(I)]\end{array}$} & $R_{1}=0.0197$ & $R_{1}=0.0395$ \\
\hline & $\mathrm{w} R_{2}=0.0490$ & $\mathrm{w} R_{2}=0.0874$ \\
\hline \multirow{2}{*}{$\begin{array}{l}R \text { indices (all } \\
\text { data) }\end{array}$} & $R_{1}=0.0256$ & $R_{1}=0.0486$ \\
\hline & $\mathrm{w} R_{2}=0.0498$ & $\mathrm{w} R_{2}=0.0897$ \\
\hline $\begin{array}{l}\text { Largest diff. peak } \\
\text { and hole }\end{array}$ & 0.571 and -0.402 & 1.649 and -1.272 \\
\hline
\end{tabular}

adopt a distorted piano-stool type of geometry with the ruthenium atom $\pi$-bonded with the benzene ring with an average $\mathrm{Ru}-\mathrm{C}$ distance of 2.1595(3) $\AA$ in $\mathbf{1}$ and 2.182(5) $\AA$ in compound $\mathbf{2}$, while the distance between the ruthenium atom and the centroid of the benzene ring is 1.418 and $1.675 \AA$ for complexes 1 and 2 , respectively. The ruthenium atom is also directly coordinated with one of the nitrogen atoms of the Hmtp or pyrimidine ligand with a normal distance. The $\mathrm{Ru}-\mathrm{Cl}$ bond lengths are also normal and comparable with other ruthenium(II) half-sandwich complexes. The angles between the nitrogen heteroaromatic ligands and chlorine ligands in the complexes $\mathbf{1}$ and $\mathbf{2}$ are close to those observed in the ruthenium-arene compounds [26]. In the structures of both complexes, inter- and intramolecular weak hydrogen bonds exist and these are [27] collected in Table 3 .

Geometry and electronic structure

To form an insight into the electronic structures and bonding properties of the complexes $\mathbf{1}$ and $\mathbf{2}$, the DFT calculations were carried out. Before calculation of electronic structures of the complexes, their geometries were optimized in singlet states using the DFT method with the B3LYP functional. From the data collected in Table 2, one may see that the majority of differences between the experimental and calculated geometries are found in the benzene ligand. The largest differences were found for the ruthenium-benzene carbon distances. The calculated $\mathrm{Ru}-$ benzene centroid distance is $1.722 \AA$ in $\mathbf{1}$ and $1.725 \AA$ in $\mathbf{2}$. The maximum differences in the bond distances are found between $\mathrm{Ru}(1)$ and $\mathrm{C}(8)$ being $0.104 \AA$ in $\mathbf{1}$ and $0.068 \AA$ in 2. For the optimized angles, the maximum differences from the experimental values are in $\mathrm{Cl}(1)-\mathrm{Ru}(1)-\mathrm{Cl}(2)$ and $\mathrm{Cl}(1)-\mathrm{Ru}(1)-\mathrm{C}(9)$ being 4.73 and $4.99^{\circ}$, respectively, for the complex of Hmtp and in $\mathrm{Cl}(1)-\mathrm{Ru}(1)-\mathrm{C}(7)$ and $\mathrm{Cl}(2)-\mathrm{Ru}(1)-\mathrm{C}(9)$ being 7.13 and $7.61^{\circ}$, respectively, for the complex with pyrimidine.

The formal charge of ruthenium is +2 in both complexes. The calculated charge on the ruthenium atom, obtained from natural population analysis, is approximately 0.2 in compound $\mathbf{1}$ and 0.18 in complex 2 . The natural atomic orbital $d$ occupancies are as follows: $d_{x y} 1.42, d_{x z}$ $1.25, d_{y z} 1.31, d_{x^{2}-y^{2}} 1.27$ and $d_{z^{2}} 1.70$ in compound 1 and $d_{x y} 1.56, d_{x z} 1.79, d_{y z} 1.34, d_{x^{2}-y^{2}} 1.16$ and $d_{z^{2}} 1.10$ in 2 . The charge on the chlorine ligands is equal to -0.38 and those on the Hmtp and pyrimidine nitrogen donor atoms are -0.47 and -0.42 , respectively. This is a result of charge donation from the ligands to the metal centre. The conclusion confirms the second-order perturbation analysis from NBO. The stabilization energy calculated in this analysis shows that the lone pairs localized on the chlorine ligand and nitrogen of Hmtp ligand donate the charge to the ruthenium $d$ orbitals, and the stabilization energy $\left(\Delta E_{i j}\right)$ is 764.61 and $138.09 \mathrm{kcal} / \mathrm{mol}$, respectively. The values of stabilization energy of charge donation from the $\mathrm{Cl}$ and $\mathrm{N}$-pyrimidine donors in complex 2 are $301.71 \mathrm{kcal} / \mathrm{mol}$ and $180.36 \mathrm{kcal} / \mathrm{mol}$, respectively. The stabilization energy associated with the charge donation from ruthenium to the $\mathrm{N}$-donor ligands is small, averaging to $6.38 \mathrm{kcal} / \mathrm{mol}$ for 


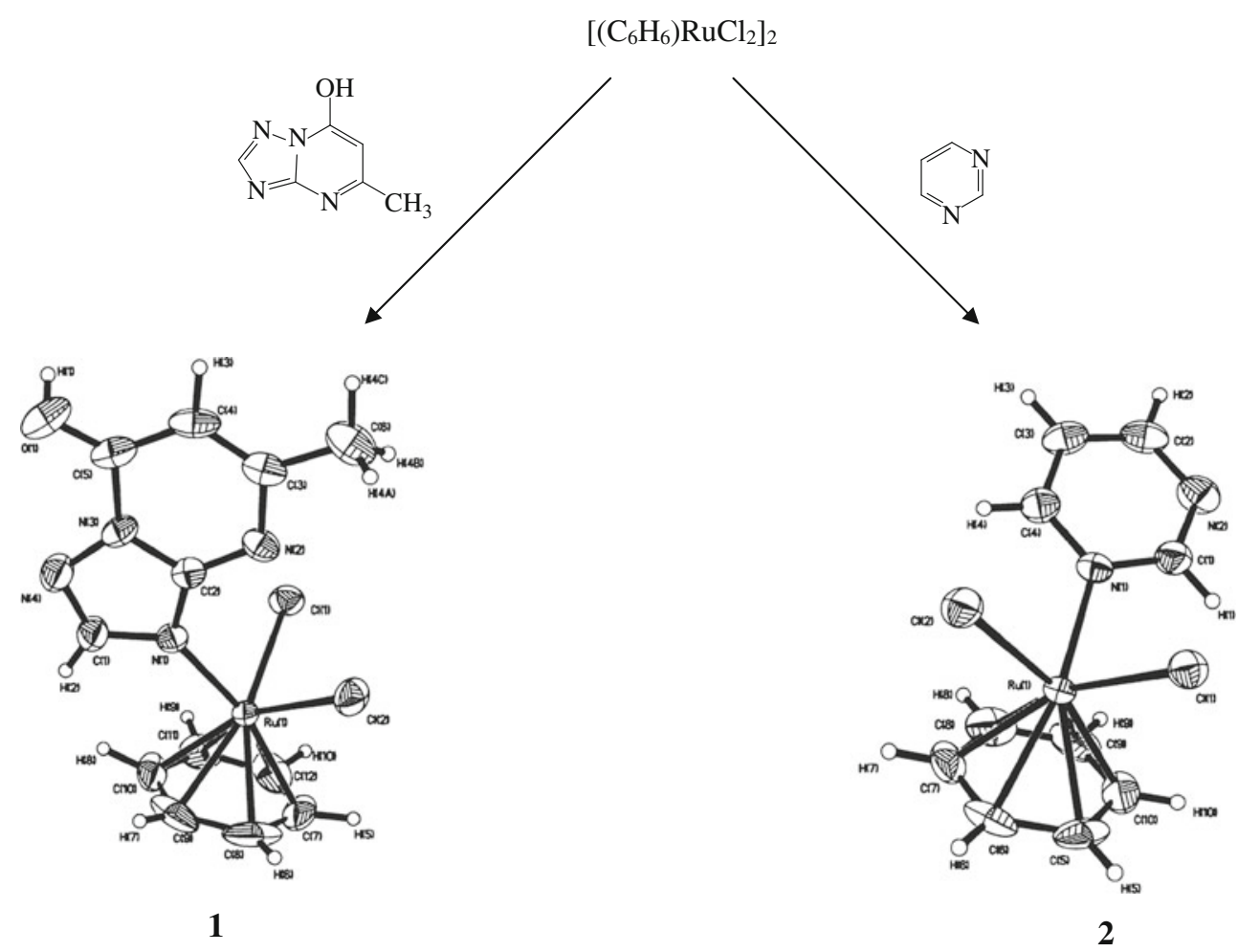

Fig. 1 ORTEP drawing of $\left[\left(\mathrm{C}_{6} \mathrm{H}_{6}\right) \mathrm{RuCl} 2(\mathrm{Hmtp})\right]$ and $\left[\left(\mathrm{C}_{6} \mathrm{H}_{6}\right) \mathrm{RuCl}_{2}\left(\mathrm{C}_{4} \mathrm{H}_{4} \mathrm{~N}_{2}\right)\right]$ with $50 \%$ probability displacement ellipsoids

complex 1 and $3.59 \mathrm{kcal} / \mathrm{mol}$ for compound 2. The stabilization energy of the charge donation from the benzene ring to the antibonding $d$ orbitals is $372.33 \mathrm{kcal} / \mathrm{mol}$ for complex 1 and 525.09 for $\mathbf{2}$, and the back donation charge from ruthenium to the benzene ring stabilizes molecules $\mathbf{1}$ and $\mathbf{2}$ by 87.99 and $87.87 \mathrm{kcal} / \mathrm{mol}$, respectively.

The atomic charge calculations can give description of the location of the electron density of the compounds. Since the electron distribution is not apparent from the partial atomic charges, Fig. 2 shows the plots of the electrostatic potentials for the complexes $\mathbf{1}$ and $\mathbf{2}$. The isoelectronic contours are plot at 0.005 a.u. $(3.1 \mathrm{kcal} / \mathrm{mol})$. The colour code of these maps is in the range of 0.05 a.u. (deepest red) to -0.005 a.u. (deepest blue), where blue indicates the strongest attraction and red indicates the strongest repulsion. Regions of negative $\mathrm{V}(\mathrm{r})$ are usually associated with the lone pairs of electronegative atoms. The negative potential in the complexes $\mathbf{1}$ and $\mathbf{2}$ encompasses the chloride atoms, hydroxyl group and heteroaromatic nitrogen.

In the frontier region, neighbouring orbitals may show quasi-degeneracy of the energetic levels. In such cases, consideration of only the HOMO and LUMO may not yield a realistic description of the frontier orbitals. For this reason, the partial density of states (DOS) and overlap population density of states (OPDOS) in terms of Mulliken population analysis were calculated using the GaussSum program. They provide a pictorial representation of the MO compositions and their contributions to chemical bonding. The DOS and OPDOS diagrams are shown in Fig. 3. The DOS plot mainly presents the composition of the fragment orbitals contributing to the molecular orbitals. The OPDOS can enable us to ascertain the bonding, non-bonding and antibonding characteristics with respect to the particular fragments. A positive value in the OPDOS plot means a bonding interaction, while a negative value represents an antibonding interaction, and a near zero value indicates a non-bonding interaction.

As can be seen from the OPDOS plot, the chloride ligands have significant antibonding character in the HOMO and HOMO-1 molecular orbitals. The interactions of the benzene ligand with the $\mathrm{Ru}(\mathrm{II}) d$ orbitals have positive values in the energy range adequate to the HOMO and HOMO-1 molecular orbitals, and in lower occupied orbitals, the interaction has antibonding character. In the frontier occupied and virtual molecular orbitals, the values of the interaction between ruthenium and the Hmtp or pyrimidine ligands are small, which indicates that these ligands are weak $\pi$-acceptors. This conclusion is confirmed on the one hand by the stabilization energy mentioned above and on the other hand by the proportion of the $\mathrm{Ru}(\mathrm{II})$ and $N$-heteroaromatic ligands in the frontier molecular orbitals and Mayer bond orders. For example, in the 
Table 2 Selected bond lengths $[\AA]$ and angles $\left[{ }^{\circ}\right]$ for $\left[\left(\mathrm{C}_{6} \mathrm{H}_{6}\right) \mathrm{RuCl}_{2}(\mathrm{Hmtp})\right](\mathbf{1})$ and $\left[\left(\mathrm{C}_{6} \mathrm{H}_{6}\right) \mathrm{RuCl}_{2}\left(\mathrm{C}_{4} \mathrm{H}_{4} \mathrm{~N}_{2}\right)\right]$ (2) with the optimized geometry values

\begin{tabular}{|c|c|c|c|c|c|}
\hline \multicolumn{3}{|l|}{1} & \multicolumn{3}{|l|}{2} \\
\hline & Exp & Calc & & Exp & Calc \\
\hline \multicolumn{6}{|l|}{ Bond lengths $[A]$} \\
\hline $\mathrm{Ru}(1)-\mathrm{N}(1)$ & $2.1477(19)$ & 2.1923 & $\mathrm{Ru}(1)-\mathrm{N}(1)$ & $2.133(3)$ & 2.1760 \\
\hline $\mathrm{Ru}(1)-\mathrm{Cl}(1)$ & $2.4198(7)$ & 2.4262 & $\mathrm{Ru}(1)-\mathrm{Cl}(1)$ & $2.4105(9)$ & 2.4159 \\
\hline $\mathrm{Ru}(1)-\mathrm{Cl}(2)$ & $2.4316(6)$ & 2.4264 & $\mathrm{Ru}(1)-\mathrm{Cl}(2)$ & $2.4157(10)$ & 2.4239 \\
\hline $\mathrm{Ru}(1)-\mathrm{C}(7)$ & $2.160(3)$ & 2.2067 & $\mathrm{Ru}(1)-\mathrm{C}(5)$ & $2.178(4)$ & 2.2177 \\
\hline $\mathrm{Ru}(1)-\mathrm{C}(8)$ & $2.133(3)$ & 2.2392 & $\mathrm{Ru}(1)-\mathrm{C}(6)$ & $2.184(4)$ & 2.2264 \\
\hline $\mathrm{Ru}(1)-\mathrm{C}(9)$ & $2.160(3)$ & 2.2520 & $\mathrm{Ru}(1)-\mathrm{C}(7)$ & $2.166(4)$ & 2.2232 \\
\hline $\mathrm{Ru}(1)-\mathrm{C}(10)$ & $2.175(3)$ & 2.2518 & $\mathrm{Ru}(1)-\mathrm{C}(8)$ & $2.194(5)$ & 2.2621 \\
\hline $\mathrm{Ru}(1)-\mathrm{C}(11)$ & $2.163(3)$ & 2.2389 & $\mathrm{Ru}(1)-\mathrm{C}(9)$ & $2.189(5)$ & 2.2243 \\
\hline $\mathrm{Ru}(1)-\mathrm{C}(12)$ & $2.166(3)$ & 2.2068 & $\mathrm{Ru}(1)-\mathrm{C}(10)$ & $2.178(4)$ & 2.2534 \\
\hline \multicolumn{6}{|l|}{ Angles $\left[{ }^{\circ}\right]$} \\
\hline $\mathrm{Cl}(1)-\mathrm{Ru}(1)-\mathrm{Cl}(2)$ & $87.34(2)$ & 92.07 & $\mathrm{Cl}(1)-\mathrm{Ru}(1)-\mathrm{Cl}(2)$ & $87.45(3)$ & 90.03 \\
\hline $\mathrm{N}(1)-\mathrm{Ru}(1)-\mathrm{Cl}(1)$ & $84.17(6)$ & 85.84 & $\mathrm{~N}(1)-\mathrm{Ru}(1)-\mathrm{Cl}(1)$ & $85.50(9)$ & 84.54 \\
\hline $\mathrm{N}(1)-\mathrm{Ru}(1)-\mathrm{Cl}(2)$ & $89.41(5)$ & 85.73 & $\mathrm{~N}(1)-\mathrm{Ru}(1)-\mathrm{Cl}(2)$ & $86.96(9)$ & 85.40 \\
\hline $\mathrm{N}(1)-\mathrm{Ru}(1)-\mathrm{C}(7)$ & $160.56(14)$ & 157.84 & $\mathrm{~N}(1)-\mathrm{Ru}(1)-\mathrm{C}(5)$ & $148.43(19)$ & 144.39 \\
\hline $\mathrm{N}(1)-\mathrm{Ru}(1)-\mathrm{C}(9)$ & $94.54(11)$ & 96.38 & $\mathrm{~N}(1)-\mathrm{Ru}(1)-\mathrm{C}(7)$ & $123.96(17)$ & 131.70 \\
\hline $\mathrm{N}(1)-\mathrm{Ru}(1)-\mathrm{C}(11)$ & $116.43(10)$ & 120.78 & $\mathrm{~N}(1)-\mathrm{Ru}(1)-\mathrm{C}(9)$ & $89.16(15)$ & 91.65 \\
\hline $\mathrm{Cl}(1)-\mathrm{Ru}(1)-\mathrm{C}(7)$ & $115.17(12)$ & 115.82 & $\mathrm{Cl}(1)-\mathrm{Ru}(1)-\mathrm{C}(5)$ & $90.02(13)$ & 87.35 \\
\hline $\mathrm{Cl}(1)-\mathrm{Ru}(1)-\mathrm{C}(9)$ & $157.53(12)$ & 152.54 & $\mathrm{Cl}(1)-\mathrm{Ru}(1)-\mathrm{C}(7)$ & $150.20(15)$ & 143.07 \\
\hline $\mathrm{Cl}(1)-\mathrm{Ru}(1)-\mathrm{C}(11)$ & $92.53(9)$ & 88.74 & $\mathrm{Cl}(1)-\mathrm{Ru}(1)-\mathrm{C}(9)$ & $123.02(14)$ & 128.19 \\
\hline $\mathrm{Cl}(2)-\mathrm{Ru}(1)-\mathrm{C}(7)$ & $89.62(10)$ & 88.68 & $\mathrm{Cl}(2)-\mathrm{Ru}(1)-\mathrm{C}(5)$ & $124.10(16)$ & 129.29 \\
\hline $\mathrm{Cl}(2)-\mathrm{Ru}(1)-\mathrm{C}(9)$ & $115.11(12)$ & 115.38 & $\mathrm{Cl}(2)-\mathrm{Ru}(1)-\mathrm{C}(7)$ & $89.65(12)$ & 86.80 \\
\hline $\mathrm{Cl}(2)-\mathrm{Ru}(1)-\mathrm{C}(11)$ & $154.03(9)$ & 153.46 & $\mathrm{Cl}(2)-\mathrm{Ru}(1)-\mathrm{C}(9)$ & $148.87(15)$ & 141.26 \\
\hline $\mathrm{C}(7)-\mathrm{Ru}(1)-\mathrm{C}(9)$ & $68.43(14)$ & 66.85 & $\mathrm{C}(5)-\mathrm{Ru}(1)-\mathrm{C}(7)$ & $67.36(18)$ & 67.03 \\
\hline $\mathrm{C}(7)-\mathrm{Ru}(1)-\mathrm{C}(11)$ & $66.97(14)$ & 67.29 & $\mathrm{C}(7)-\mathrm{Ru}(1)-\mathrm{C}(9)$ & $67.25(19)$ & 66.72 \\
\hline $\mathrm{C}(9)-\mathrm{Ru}(1)-\mathrm{C}(11)$ & $67.90(13)$ & 66.55 & $\mathrm{C}(5)-\mathrm{Ru}(1)-\mathrm{C}(9)$ & $67.3(2)$ & 66.83 \\
\hline
\end{tabular}

Table 3 Hydrogen bonds for $\left[\left(\mathrm{C}_{6} \mathrm{H}_{6}\right) \mathrm{RuCl}_{2}(\mathrm{Hmtp})\right](\mathbf{1})$ and $\left[\left(\mathrm{C}_{6} \mathrm{H}_{6}\right)\right.$ $\left.\mathrm{RuCl}_{2}\left(\mathrm{C}_{4} \mathrm{H}_{4} \mathrm{~N}_{2}\right)\right](2)\left(\AA\right.$ and $\left.{ }^{\circ}\right)$

\begin{tabular}{lllll}
\hline $\mathrm{D}-\mathrm{H} \ldots \mathrm{A}$ & $\mathrm{d}(\mathrm{D}-\mathrm{H})$ & $\mathrm{d}(\mathrm{H} \ldots \mathrm{A})$ & $\mathrm{d}(\mathrm{D} \ldots \mathrm{A})$ & $<(\mathrm{DHA})$ \\
\hline $\mathbf{1}$ & & & & \\
$\mathrm{C}(1)-\mathrm{H}(2) \ldots \mathrm{Cl}(1) \# 1$ & 0.93 & 2.81 & $3.703(3)$ & 161.3 \\
$\mathrm{C}(10)-\mathrm{H}(8) \ldots \mathrm{Cl}(1) \# 1$ & 0.98 & 2.78 & $3.683(3)$ & 153.9 \\
$\mathrm{C}(7)-\mathrm{H}(5) \ldots \mathrm{O}(1) \# 2$ & 0.98 & 2.50 & $3.358(4)$ & 145.6 \\
$\mathrm{C}(12)-\mathrm{H}(10) \ldots \mathrm{N}(4) \# 3$ & 0.98 & 2.55 & $3.292(4)$ & 132.6 \\
$\mathbf{2}$ & & & & \\
$\mathrm{C}(4)-\mathrm{H}(4) \ldots \mathrm{Cl}(2)$ & 0.93 & 2.80 & $3.267(4)$ & 112.6 \\
$\mathrm{C}(7)-\mathrm{H}(7) \ldots \mathrm{Cl}(1) \# 4$ & 0.93 & 2.74 & $3.561(5)$ & 147.0 \\
\hline
\end{tabular}

Symmetry transformations used to generate equivalent atoms: \#1 $1 / 2-\mathrm{x},-1 / 2+\mathrm{y}, 1 / 2-\mathrm{z} ; \# 2-1 / 2+\mathrm{x}, 1 / 2+\mathrm{y}, \mathrm{z} ; \# 31 / 2-\mathrm{x}$, $1 / 2+y, 1 / 2-\mathrm{z} ; \# 4 \mathrm{x}, 1 / 2-\mathrm{y}, 1 / 2+\mathrm{z}$

HOMO, HOMO- 1 and HOMO-2, the $d$ ruthenium orbitals contribute 35,30 and $27 \%$ in complex $\mathbf{1}$ and $38,31,35 \%$ in 2, and the Hmtp and pyrimidine ligands only 1, 3, 5\% and $2,2,3 \%$, respectively. On the other hand, HOMO-3 in complex $\mathbf{1}$ and HOMO-10 in $\mathbf{2}$ are localized on the Hmtp (94\%) and pyrimidine (94\%) fragments. Furthermore, the
Mayer bond orders for $\mathrm{Ru}-\mathrm{N}(1)$ of 0.71 for complex 1 and 0.79 for 2 show the weakness of this bond compared with the $\mathrm{Ru}-\mathrm{Cl}$ (1.75) bond. The bond between the benzene ring and ruthenium is slightly more covalent in complex $\mathbf{2}$ $(0.90-0.78)$ than in the complex with Hmtp (0.85-0.71). In the two lowest virtual orbitals, an interaction of the ruthenium $d$ orbital (LUMO 54\%; LUMO + $145 \%, 55 \%$ for $\mathbf{1}$ and $\mathbf{2}$, respectively) with benzene $\pi$ orbitals (31\%, $19 \%$ in 1 and $23,27 \%$ in 2) is visible. Additionally, the $d$ ruthenium (22, 27\% for $\mathbf{1} ; 26,20 \%$ for 2 ) and $\pi$ benzene $(71,69 \% ; 77,71 \%)$ orbitals play a significant role in the LUMO +4 and LUMO +5 molecular orbitals. The LUMO $+2(97 \%)$ is localized on the Hmtp fragment in complex 2, while the LUMO (96\%) and LUMO + $3(96 \%)$ are localized on the pyrimidine moiety.

The energy decomposition analysis of the complexes, based on the work of Morokuma [28-30], and the extended transition state (ETS) partitioning scheme of Ziegler $[31,32]$ have been carried out using the ADF program (Release 2008) [33] at the level of B3LYP/TZP. The binding energy of each compound was calculated as the difference between the energy of the geometry optimized 

(ESP) surfaces of complexes $\mathbf{1}$ and 2. ESP surface is shown both in space (with positive and negative regions shown in red and blue, respectively) and mapped on electron densities (isovalue $=0.005)$ of the molecule (ESP colour scale is such that $\delta^{+} \rightarrow \delta^{-}$in the direction red $\rightarrow$ blue).

(Color figure online)
Fig. 2 Electrostatic potential
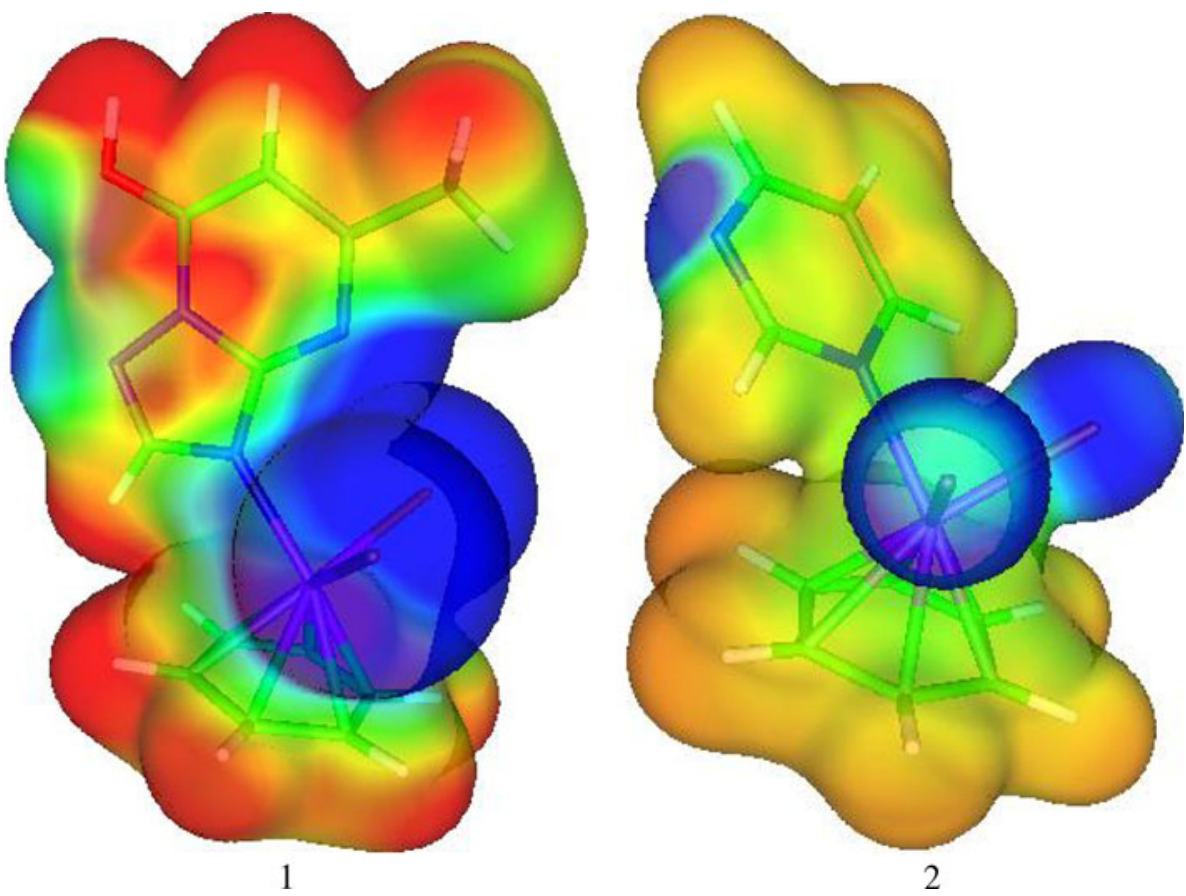

Fig. 3 The density of states (DOS) and overlap partial density of states (OPDOS) diagrams for $\left[\left(\mathrm{C}_{6} \mathrm{H}_{6}\right) \mathrm{RuCl}_{2}(\mathrm{Hmtp})\right](\mathbf{1})$ and $\left[\left(\mathrm{C}_{6} \mathrm{H}_{6}\right) \mathrm{RuCl}_{2}\left(\mathrm{C}_{4} \mathrm{H}_{4} \mathrm{~N}_{2}\right)\right]$ (2)
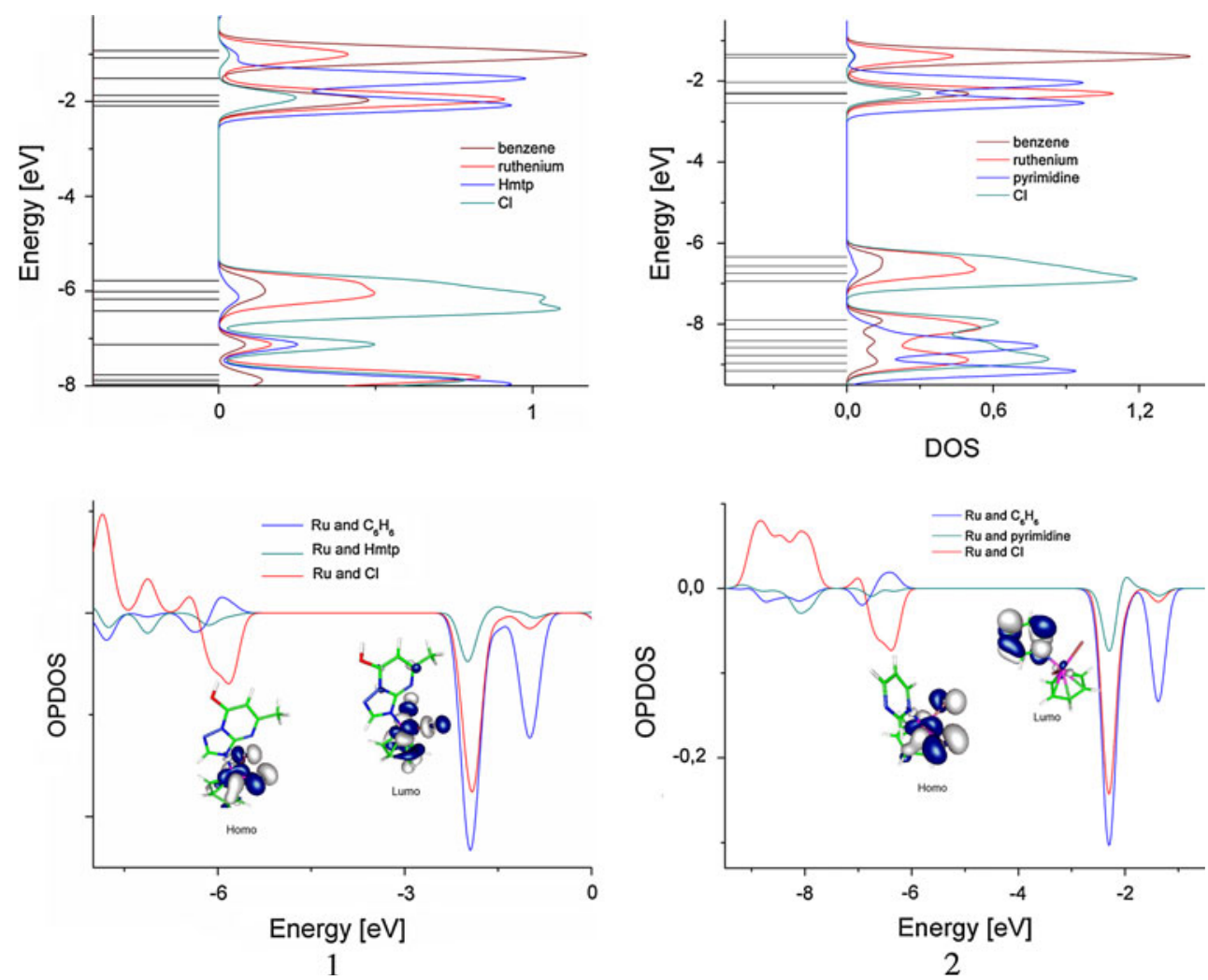

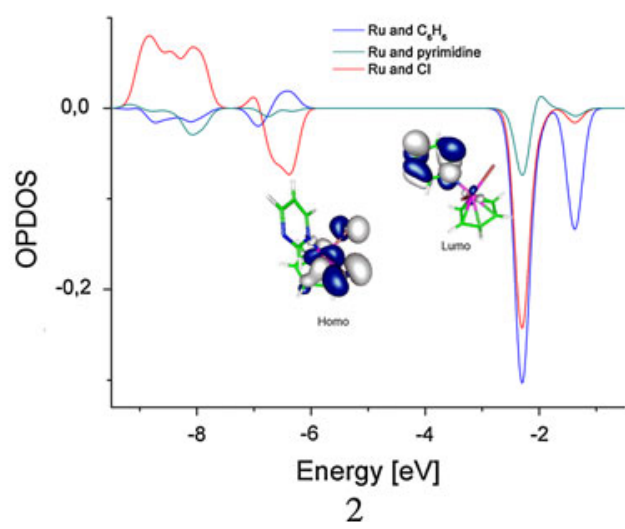

complexes and the energies of the optimized free ligands Hmtp and pyrimidine and the $\left[\left(\mathrm{C}_{6} \mathrm{H}_{6}\right) \mathrm{RuCl}_{2}\right]$ fragment. The general theoretical background on the bond energy decomposition scheme has been reviewed [34]. In Table 4, are listed the results of energy decomposition analysis calculated for the complexes in the gas phase and in methanol solvent. As one can see, the kinetic and Coulomb (steric and orbital interaction) energies play an important role for the $\left[\left(\mathrm{C}_{6} \mathrm{H}_{6}\right) \mathrm{RuCl}_{2}\right]-\mathrm{Hmtp}$ binding in solution, and in the case of complex 2 , the kinetic energy plays the dominant role. The calculated bonding energies for the two compounds are close to each other, which suggests 
Table 4 Energy decomposition analysis for complexes $\left[\left(\mathrm{C}_{6} \mathrm{H}_{6}\right) \mathrm{RuCl}_{2}(\mathrm{Hmtp})\right]$ and $\left[\left(\mathrm{C}_{6} \mathrm{H}_{6}\right) \mathrm{RuCl}_{2}\left(\mathrm{C}_{4} \mathrm{H}_{4} \mathrm{~N}_{2}\right)\right]$ in the $\left[\left(\mathrm{C}_{6} \mathrm{H}_{6}\right) \mathrm{RuCl}_{2}\right]$ fragment and the Hmtp, pyrimidine ligands (energies in $\mathrm{kcal}^{\prime} \mathrm{mol}^{-1}$ )

\begin{tabular}{lccccc}
\hline Energy $[\mathrm{kcal} / \mathrm{mol}]$ & \multicolumn{2}{c}{$\left[\left(\mathrm{C}_{6} \mathrm{H}_{6}\right) \mathrm{RuCl}_{2}(\mathrm{Hmtp})\right]$} & & \multicolumn{2}{c}{$\left[\left(\mathrm{C}_{6} \mathrm{H}_{6}\right) \mathrm{RuCl}_{2}\left(\mathrm{C}_{4} \mathrm{H}_{4} \mathrm{~N}_{2}\right)\right]$} \\
\cline { 2 - 3 } & Gas phase & $\mathrm{CH}_{3} \mathrm{OH}$ solvent & & Gas phase & $\mathrm{CH}_{3} \mathrm{OH}$ solvent \\
\hline$\Delta \mathrm{E}_{\text {elstat }}$ & -71.66 & -72.69 & & -86.47 & -86.47 \\
$\Delta \mathrm{E}_{\text {kinetic }}$ & 104.24 & 53.34 & & 143.61 & 207.95 \\
$\Delta \mathrm{E}_{\text {Coulomb (Steric+OrbInt) }}$ & -14.41 & 59.29 & & -38.98 & -78.23 \\
$\Delta \mathrm{E}_{\mathrm{XC}}$ & -41.42 & -48.13 & & -49.12 & -64.65 \\
$\Delta \mathrm{E}_{\text {solvation }}$ & & -45.05 & & & -29.60 \\
$\Delta \mathrm{E}$ & -23.25 & -53.24 & & -30.96 & -50.99 \\
\hline
\end{tabular}

similarities in $\pi$-accepting properties of the Hmtp and pyrimidine ligands.

\section{Electronic spectrum}

The UV-Vis spectra of the complexes displayed bands with maxima at 445, 337, 272, 234 and $213 \mathrm{~nm}$ for $\left[\left(\mathrm{C}_{6} \mathrm{H}_{6}\right) \mathrm{RuCl}_{2}(\mathrm{Hmtp})\right]$ and 410, 302, 271, 231 and $213 \mathrm{~nm}$ for $\left[\left(\mathrm{C}_{6} \mathrm{H}_{6}\right) \mathrm{RuCl}_{2}\left(\mathrm{C}_{4} \mathrm{H}_{4} \mathrm{~N}_{2}\right)\right]$. The assignments of the calculated transitions to the experimental bands are based on the criteria of energy and oscillator strength of the calculated transitions. In the description of the electronic transitions, only the main components of the molecular orbitals are taken into consideration.

The two asymmetric and broad experimental bands in the visible region of the electronic spectra of the complexes $\mathbf{1}$ and $\mathbf{2}$ are assigned to the transitions between the HOMO, HOMO-1, HOMO-2 and LUMO, LUMO + 1 and LUMO + 2 molecular orbitals. As the HOMO, HOMO-1, HOMO- 2 and LUMO +1 , LUMO +2 are composed of the $d$ ruthenium orbitals with admixture of $\pi$-benzene, the transitions are of Ligand Field type ( $\rightarrow$ d). The LUMOs are localized on the Hmtp and pyrimidine ligands, respectively, in complexes $\mathbf{1}$ or $\mathbf{2}$, and Metal-Ligand Charge Transfer transitions are associated with these. The bands observed at 272 and $271 \mathrm{~nm}$ have been attributed to the Metal-Ligand and Ligand-Metal Charge Transfer transitions ( $\mathrm{d} \rightarrow \pi^{*}{ }_{\text {benzene/Hmtp/pyrimidine/Cl }} ; \pi^{*}$ Hmtp/pyrimidine $\rightarrow \mathrm{d}$ ). In this energy region, the transitions between the HOMO$3 \rightarrow$ LUMO +1 (92\% in both complexes), HOMO$3 \rightarrow$ LUMO $(93 \%)$ and HOMO-2 $\rightarrow$ LUMO $+3(88 \%)$ were calculated. The highest energy bands with maxima at $213 \mathrm{~nm}$ and $213 \mathrm{~nm}$ are attributed to transitions of the Ligand-Ligand Charge Transfer type $\left(\pi \rightarrow \pi^{*}{ }_{\mathrm{C}=\mathrm{N}}\right)$.

Based on the pseudooctahedral geometry of these and taking into account the $\mathrm{d}-\mathrm{d}$ transitions assigned to ${ }^{1} \mathrm{~A}_{1} \rightarrow{ }^{1} \mathrm{~T}_{1}$ and ${ }^{1} \mathrm{~A}_{1} \rightarrow{ }^{1} \mathrm{~T}_{2}$ in octahedral symmetry (or ${ }^{1} \mathrm{~A}_{1} \rightarrow{ }^{1} \mathrm{~A}_{2} / \mathrm{B}_{1} / \mathrm{B}_{2}$ in lower symmetry fields as $\mathrm{C}_{2 \mathrm{v}}$ ), the ligand field parameters $10 \mathrm{Dq}$ can be estimated to 2,9847 and $27,158 \mathrm{~cm}^{-1}$ for the complexes $\mathbf{1}$ and $\mathbf{2}$, respectively. Racah's parameters for complexes $\mathbf{1}$ and $\mathbf{2}$ are $B=598$, $544 \mathrm{~cm}^{-1} ; C=2,380,2,166 \mathrm{~cm}^{-1}$, respectively, and the nephelauxetic parameters have values $\beta_{55}=0.83$ and 0.76 , respectively. The differences in these parameters are in accordance with the covalence (Mayer bond orders) of these complexes.

The emission characteristics of complex $\mathbf{1}$ have been examined in acetonitrile solution $\left(1 \times 10^{-3} \mathrm{~mol} / \mathrm{dm}^{3}\right)$ at room temperature. Excitation at $370 \mathrm{~nm}$ gave an intense unsymmetrical emission peak with maximum at $480 \mathrm{~nm}$. The unsymmetrical structure of the luminescence spectrum suggests that more than one state is involved in the luminescence process. Hence, the luminescence is of IL/MLCT origin in this system.

\section{Conclusion}

From the reactions between $\left[\left(\mathrm{C}_{6} \mathrm{H}_{6}\right) \mathrm{RuCl}_{2}\right]_{2}$ and 7-hydroxy5 -methyl-[1,2,4]triazolo[1,5-a]pyrimidine or pyrimidine in methanol, two new half-sandwich ruthenium(II) complexes were obtained. Both complexes are neutral. The molecular structures of the compounds were determined by X-ray crystallography, and the spectroscopic properties were studied. Based on the crystal structures, computational studies were made to determine the electronic structures and UV-Vis spectra of the complexes. The results indicate that the Hmtp and pyrimidine ligands have similar $\pi$-acceptor properties, being rather weak $\pi$-acceptors.

\section{Appendix A. Supplementary data}

CCDC 755383 and CCDC 757130 contain the supplementary crystallographic data for complexes $\left[\left(\mathrm{C}_{6} \mathrm{H}_{6}\right) \mathrm{RuCl}_{2^{-}}\right.$ (Hmtp)] and $\left[\left(\mathrm{C}_{6} \mathrm{H}_{6}\right) \mathrm{RuCl}_{2}\left(\mathrm{C}_{4} \mathrm{H}_{4} \mathrm{~N}_{2}\right)\right]$, respectively. These data can be obtained free of charge from http://www.ccdc. cam.ac.uk/conts/retrieving.html, or from the Cambridge Crystallographic Data Centre, 12 Union Road, Cambridge CB2 1EZ, UK; fax: (+44) 1223-336-033; or e-mail: deposit@ccdc.cam.ac.uk.

The Gaussian09 calculations were carried out in Wrocław Centre for Networking and Supercomputing, WCSS, Wrocław, Poland. 
Open Access This article is distributed under the terms of the Creative Commons Attribution Noncommercial License which permits any noncommercial use, distribution, and reproduction in any medium, provided the original author(s) and source are credited.

\section{References}

1. Kumar KN, Venkatachalam G, Ramesh R, Liu Y (2008) Polyhedron 27:157

2. Rawling T, McDonagh A (2007) Coord Chem Rev 251:1128

3. Rawling T, McDonagh AM, Colbran SB (2008) Inorg Chim Acta 361:49

4. Lu X-Y, Xu H-J, Chen T-X (2009) Inorg Chem Commun 12:887

5. Therien B (2009) Coord Che Rev 253:493

6. Pampaloni G (2010) Coord Che Rev 254:402

7. Ronconi L, Sadler JP (2007) Coord Che Rev 251:1633

8. de los Rios I, Tenerio MJ, Tenorio MAJ, Puerta MC, Valerga P (1996) J Organomet Chem 525:57

9. Schlüter A, Bieber K, Sheldrick WS (2002) Inorg Chim Acta 340:35

10. Chen Y, Valentini M, Pregosin PS, Albinati A (2002) Inorg Chim Acta 327:4

11. Singh A, Singh N, Pandey DS (2002) J Organomet Chem 642:48

12. Allardyce CS, Dyson PJ, Ellis DJ, Heath SL (2001) Chem Commun (15): 1396

13. Chen H, Parkinson JA, Parsons S, Coxall RA, Gould RO, Sadler PJ (2002) J Am Chem Soc 124:3064

14. Aird RE, Cummings J, Ritchie AA, Muir M, Morris RE, Chen H, Sadler PJ, Jodrell DI (2002) Brit J Cancer 86:1652

15. Morris RE, Aird RE, Del P, Murdoch S, Chen H, Cummings J, Hughes ND, Parsons S, Parkin A, Boyd G, Jodrell DI, Sadler PJ (2001) J Med Chem 44:3616

16. Sorrell TN, Borovik AS (1986) J Am Chem Soc 108:2479

17. Kusama H, Arakawa H, Sugihara H (2005) J Photochem Photobio A Chem 171:201

18. Daly DA, Martin LL (2002) Inorg Chem Commun 5:777

19. Buchmueller KL, Staples AM, Howard CM, Horick SM, Uthe PB, Le NM, Cox KK, Nguyen B, Pacheco KAO, Wilson WD, Lee M (2005) J Am Chem Soc 127:742

20. Bennett MA, Huang T-N, Matheson TW, Smith AK (1982) Inorg Synth 21:74

21. Gaussian 09, Revision A.1, Frisch MJ, Trucks GW, Schlegel HB, Scuseria GE, Robb MA, Cheeseman JR, Scalmani G, Barone V,
Mennucci B, Petersson GA, Nakatsuji H, Caricato M, Li X, Hratchian HP, Izmaylov AF, Bloino J, Zheng G, Sonnenberg JL, Hada M, Ehara M, Toyota K, Fukuda R, Hasegawa J, Ishida M, Nakajima $T$, Honda $Y$, Kitao $O$, Nakai $H$, Vreven $T$, Montgomery, Jr. JA, Peralta JE, Ogliaro F, Bearpark M, Heyd JJ, Brothers E, Kudin KN, Staroverov VN, Kobayashi R, Normand J, Raghavachari K, Rendell A, Burant JC, Iyengar SS, Tomasi J, Cossi M, Rega N, Millam JM, Klene M, Knox JE, Cross JB, Bakken V, Adamo C, Jaramillo J, Gomperts R, Stratmann RE, Yazyev O, Austin AJ, Cammi R, Pomelli C, Ochterski JW, Martin RL, Morokuma K, Zakrzewski VG, Voth GA, Salvador P, Dannenberg JJ, Dapprich S, Daniels AD, Farkas O, Foresman JB, Ortiz JV, Cioslowski J, Fox DJ (2009) Gaussian, Inc., Wallingford, $\mathrm{CT}$

22. Becke AD (1993) J Chem Phys 98:5648

23. Lee C, Yang W, Parr RG (1988) Phys Rev B 37:785

24. Casida ME (1996) Recent developments and applications of modern density functional theory. In: Seminario JM (ed) Theoretical and computational chemistry, vol 4. Elsevier, Amsterdam, p 391

25. Eichkorn K, Weigend F, Treutler O, Ahlrichs R (1997) Theor Chim Acc 97:119

26. O'Boyle NM, Tenderholt AL, Langner KM (2008) J Comp Chem 29:839

27. Dolomanov et al. (2009) J Appl Cryst 42:339-341

28. Tribo R, Pons J, Yanez R, Piniella JF, Alvarez-Larena A, Ros J (2000) Inorg Chem Commun 3:545

29. Jahncke M, Neels A, Stoeckli-Evans H, Süss-Fink G (1998) J Organomet Chem 561:227

30. Kurosawa H, Asano H, Miyaki Y (1998) Inorg Chim Acta 270:87

31. Desiraju GR, Steiner T (1999) The weak hydrogen bond in structural chemistry and biology. Oxford University Press, Oxford

32. Jeffrey GA, Saenger W (1994) Hydrogen bonding in biological structures. Springer, New York

33. Morokuma KJ (1971) Chem Phys Lett 9:129

34. Ziegler T, Rauk A (1977) Theor Chim Acta 46:1

35. ADF2009.01, SCM, Theoretical Chemistry, Vrije Universiteit, Amsterdam, The Netherlands, http://www.scm.com

36. Bickelhaupt FM, Baerends EJ (2000) Kohn-Sham density functional theory: predicting and understanding chemistry. In: Lipkowitz KB, Boyd DB (eds) Rev. Comput. Chem., vol 15. Wiley, New York, pp 1-86 